\title{
Design Model Free Switching Gain Scheduling Baseline Controller with Application to Automotive Engine
}

\author{
Farzin Piltan \\ Industrial Electrical and Electronic Engineering SanatkadeheSabze Pasargad. CO (S.S.P. Co), NO:16 , PO.Code \\ 71347-66773, Fourth floor, Dena Apr, Seven Tir Ave, Shiraz, Iran \\ Email: SSP.ROBOTIC@g mail.com
}

Mehdi Akbari

Industrial Electrical and Electronic Engineering SanatkadeheSabze Pasargad. CO (S.S.P. Co), NO:16 , PO.Code 71347-66773, Fourth floor, Dena Apr, Seven Tir Ave, Shiraz, Iran Email: SSP.ROBOTIC@yahoo.com

Mojdeh Piran

Industrial Electrical and Electronic Engineering SanatkadeheSabze Pasargad. CO (S.S.P. Co), NO:16 , PO.Code 71347-66773, Fourth floor, Dena Apr, Seven Tir Ave, Shiraz, Iran

Email: SSP.ROBOTIC@yahoo.com

\author{
Mansour Bazregar \\ Industrial Electrical and Electronic Engineering SanatkadeheSabze Pasargad. CO (S.S.P. Co), NO:16 , PO.Code \\ 71347-66773, Fourth floor, Dena Apr, Seven Tir Ave, Shiraz, Iran \\ Email: SSP.ROBOTIC@yahoo.com
}

\begin{abstract}
Internal combustion (IC) engines are optimized to meet exhaust emission requirements with the best fuel economy. Closed loop combustion control is a key technology that is used to optimize the engine combustion process to achieve this goal. In order to conduct research in the area of closed loop combustion control, a control oriented cycle-to-cycle engine model, containing engine combustion information for each individual engine cycle as a function of engine crank angle, is a necessity. This research aims to design a new methodology to fix the fuel ratio in internal combustion (IC) engine. Baseline method is a linear methodology which can be used for highly nonlinear system's (e.g., IC engine). To optimize this method, new linear part sliding mode method (NLPSM) is used. This online optimizer can adjust the optimal coefficient to have the best performance.
\end{abstract}

Index Terms - IC Engine, Fuel Ratio, Port Fuel Injection, Direct Injection, Baseline Method, Linear Part Sliding Mode Method

\section{Introduction}

The internal combustion (IC) engine is designed to produce power from the energy that is contained in its fuel. More specifically, its fuel contains chemical energy and together with air, this mixture is burned to output mechanical power [1-3]. In an internal combustion engine, a piston moves up and down in a cylinder and power is transferred through a connecting rod to a crank shaft. The continual motion of the piston and rotation of the crank shaft as air and fuel enter and exit the cylinder through the intake and exhaust valves is known as an engine cycle. The fuel ratio can be used to determine which fuel system should have a larger impact on how much fuel is injected into the cylinder [4-9]. Since a direct fuel injector (DI) has immediate injection of its fuel with significant charge cooling effect, it can have a quicker response to the desired amount of fuel that is needed by an engine. Although a port fuel injector (PFI) may have a slower response due to its wall-wetting dynamics, the fuel ratio will impact the combustion characteristics of an engine. Fuel ratio also can be used to regulate or control two fuel types. For example, an engine may have the ability to run on gasoline and ethanol. The gasoline could be injected by a PFI, while the ethanolcould be injected by a DI [1-9].

Controller is a device which can sense information from linear or nonlinear system to improve the systems performance [10-20]. The main targets to design control systems (e.g., IC engines) are FR stability, good alternative torque load rejection, and small FR error[5]. 
Several automotive engines are controlled by linear methodologies (e.g., Proportional-Derivative (PD) controller, Proportional- Integral (PI) controller or Proportional- Integral-Derivative (PID) controller), but when this systems works with various torque loads and have uncertainty in dynamic models this technique has limitations. In some applications automotive engines are used in unknown and unstructured environment, therefore strong mathematical tools used in new control methodologies to design high performance controller with acceptable performance. Baseline controller is an influential linear cascade controller to certain and partly uncertain systems which it is free of system's dynamic model [21-40]. To control of this system linear baseline methodology is introduced. Baseline methodology (BM) is an influential linear controller to certain and partly uncertain system dynamic. This methodology is work based on system's performance. When all dynamic and physical parameters are known baseline methodology works superbly; practically a large amount of systems have external disturbance and gain scheduling methodology reduce this kind of limitation. In various dynamic parameters systems that need to be training online adaptive control methodology is used. Adaptive control methodology can be classified into two main groups, namely, gain scheduling method and fuzzy adaptive method [41-55]. Gain scheduling method is used in systems which main controller is work based on conventional methodology. In this research in order to solve disturbance rejection and uncertainty dynamic parameter, switching gain scheduling adaptive method is applied to baseline methodology. Sliding fuel methodology (SFM) is a powerful nonlinear robust controller under condition of partly uncertain dynamic parameters of IC engine [10-30]. Chattering phenomenon and nonlinear equivalent dynamic formulation in uncertain dynamic parameter are two main drawbacks in SFM [33-39]. The chattering phenomenon problem in SFM is reduced by using linear saturation boundary layer function but proves the stability is very difficult and increases the error. Baseline partly sliding fuel method (BPSFM) is an influential nonlinear method optimizer to certain and partly uncertain systems which it is based on combine baseline and partly sliding mode method.

\section{Theory}

\subsection{Dynamic Formulation of IC Engine}

Dynamic modeling of IC engine is used to describe the nonlinear behavior of IC engine, design of model based controller such as pure variable structure controller based on nonlinear dynamic equations, and for simulation. The dynamic modeling describes the relationship between fuel to air ratio to PFI and DI and also it can be used to describe the particular dynamic effects (e.g., motor pressure, angular speed, mass of air in cylinder, and the other parameters) to behavior of system[1].

The equation of an IC engine governed by the following equation $[1,4,25,29,43-44]$ :

$$
\begin{aligned}
& {\left[\begin{array}{c}
\text { PFI } \\
\text { DI }
\end{array}\right]=\left[\begin{array}{ll}
\dot{\mathbf{M}}_{\text {air } 11} & \dot{\mathbf{M}}_{\text {air } 12} \\
\dot{\mathbf{M}}_{\text {air } 21} & \dot{\mathbf{M}}_{\text {air } 22}
\end{array}\right]\left[\begin{array}{c}
\ddot{F R} \\
\ddot{\boldsymbol{\alpha}}_{\mathrm{I}}
\end{array}\right] } \\
&+\left[\begin{array}{l}
\mathbf{P}_{\text {motor }} \\
\mathbf{P}_{\text {motor }}
\end{array}\right]\left[\begin{array}{ll}
\mathbf{F R} & \dot{\alpha}_{\mathrm{I}}
\end{array}\right] \\
&+\left[\begin{array}{ll}
\mathbf{N}_{11} & \mathbf{N}_{12} \\
\mathbf{N}_{21} & \mathbf{N}_{22}
\end{array}\right] \times\left[\begin{array}{c}
\mathbf{F R} \\
\dot{\dot{\alpha}_{I}}
\end{array}\right]^{2} \\
&+\left[\begin{array}{l}
\mathbf{M}_{\mathrm{a}_{1}} \\
\mathbf{M}_{\mathrm{a}_{2}}
\end{array}\right]
\end{aligned}
$$

Where $P F I$ is port fuel injector, $D I$ is direct in jector, $\dot{\mathbf{M}}_{\text {air }}$ is a symmetric and positive define mass of air matrix, $\mathbf{P}_{\text {motor }}$ is the pressure of motor, $N$ is engine angular speed and $\mathbf{M}_{\mathbf{a}}$ is matrix mass of air in cylinder. Fuel ratio and exhaust angle are calculated by $[25,29$, 43-44]:

$$
\begin{aligned}
& {\left[\begin{array}{c}
F \ddot{R}_{a} \\
\ddot{\alpha}_{I a}
\end{array}\right]=\left[\begin{array}{ll}
\dot{M}_{\text {air } 11} & \dot{M}_{\text {air } 12} \\
\dot{M}_{\text {air } 21} & \dot{M}_{\text {air } 22}
\end{array}\right]^{-1}\left\{\left[\begin{array}{c}
P F I \\
D I
\end{array}\right]\right.} \\
&-\left\{\left[\begin{array}{l}
P_{\text {motor } 1} \\
P_{\text {motor } 2}
\end{array}\right]\left[\begin{array}{ll}
F R & \dot{\alpha}_{I_{a}}
\end{array}\right]\right. \\
&+\left[\begin{array}{ll}
N_{11} & N_{12} \\
N_{21} & N_{22}
\end{array}\right] \\
&\left.\times\left[\begin{array}{c}
F \dot{R}_{a} \\
\alpha_{I_{a}}
\end{array}\right]^{2}+\left[\begin{array}{c}
M_{a_{1}} \\
M_{a_{2}}
\end{array}\right]\right\}
\end{aligned}
$$

The above target equivalence ratio calculation will be combined with fuel ratio calculation that will be used for controller design purpose.

\subsection{Baseline Methodology}

Design of a baseline methodology to control of fuel ratio was very straight forward. Since there was an output from the fuel ratio model, this means that there would be two inputs into the baseline controller. Similarly, the output of the controller result from the two control inputs of the port fuel injector signal and direct injector signal. In a typical PID method, the controller corrects the error between the desired input value and the measured value. Since the equivalence ratio and fuel ratio are the two measured signals, two controllers were cascaded together to control the PFI and DI inputs. The first was a PID controller that corrected the error between the desired equivalence ratio and the measured equivalence ratio; while the second was only a proportional integral (PI) controller that corrected the fuel ratio error. Figure 1 is shown based line methodology, applied to IC engine. 


$$
\begin{array}{r}
e_{1}(t)=\alpha_{\text {target }}(t)-\alpha_{d}(t) \\
e_{2}(t)=\text { Fuel ratio }(t) \\
\quad-\text { Fuel Ratio }_{d}(t) \\
P_{\text {FI I }}=K_{p_{a}} e_{1}+K_{V_{a}} e_{1}+K_{I_{a}} \sum e_{1}
\end{array}
$$

$$
\begin{aligned}
& D I_{\alpha}=K_{p_{b}} e_{1}+K_{V_{b}} e_{1}+K_{I_{b}} \sum e_{1} \\
& P F I_{F}=\left(K_{p_{c}} e_{2}+K_{I_{c}} \sum e_{2}\right) \times P F I_{\alpha} \\
& D I_{F}=D I_{\alpha}
\end{aligned}
$$

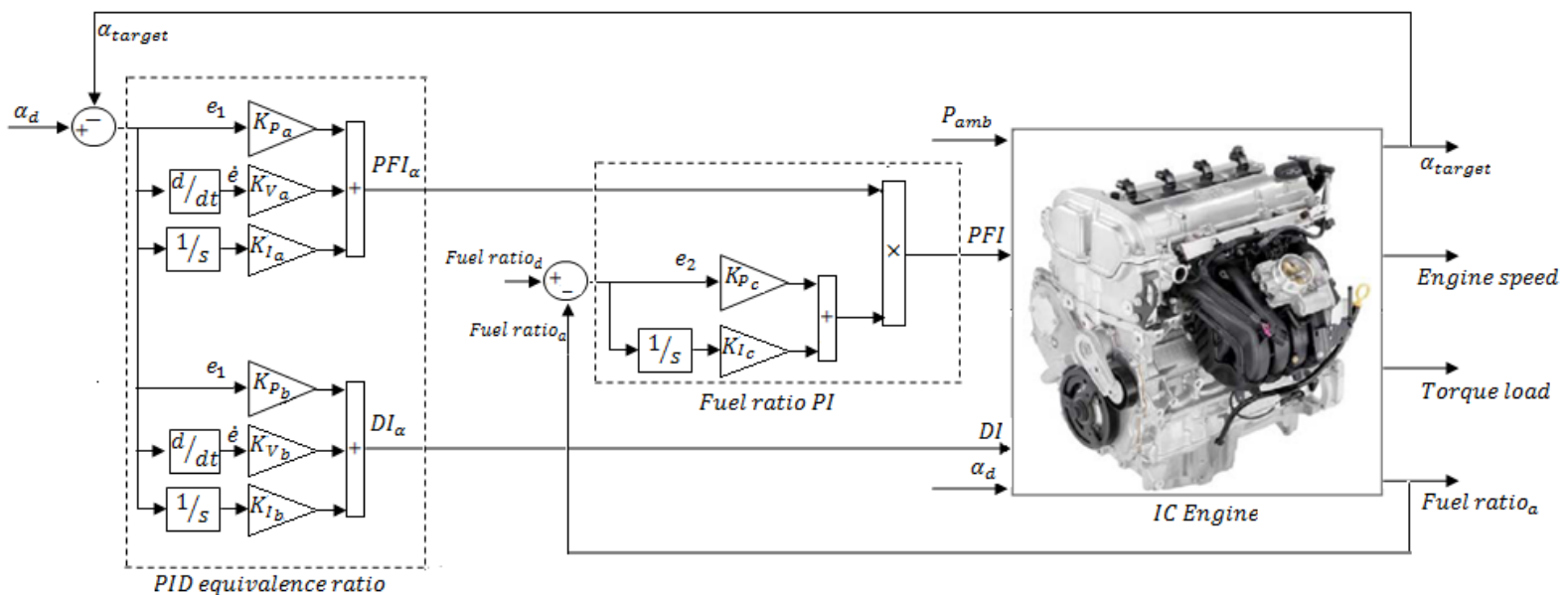

Fig. 1: Block diagram of baseline method

\subsection{Sliding Fuel Methodology}

Consider a nonlinear single input dynamic system is defined by [11]:

$$
x^{(n)}=f(\vec{x})+b(\vec{x}) u
$$

Where $\mathrm{u}$ is the vector of control input, $\boldsymbol{x}^{(\boldsymbol{n})}$ is the $\boldsymbol{n}^{\boldsymbol{t h}}$ derivation of $x, x=\left[x, \dot{x}, \ddot{x}, \ldots, x^{(n-1)}\right]^{T}$ is the state vector, $\boldsymbol{f}(\boldsymbol{x})$ is unknown or uncertainty, and $\boldsymbol{b}(\boldsymbol{x})$ is of known sign function. The main goal to design this controller is train to the desired state; $\boldsymbol{x}_{\boldsymbol{d}}=$ $\left[\boldsymbol{x}_{d}, \dot{\boldsymbol{x}}_{d}, \ddot{\boldsymbol{x}}_{d}, \ldots, \boldsymbol{x}_{d}{ }^{(\boldsymbol{n}-1)}\right]^{\boldsymbol{T}}$, and trucking error vector is defined by [16]:

$$
\widetilde{x}=x-x_{d}=\left[\widetilde{x}, \ldots, \widetilde{x}^{(n-1)}\right]^{T}
$$

A time-varying sliding surface $\boldsymbol{s}(\boldsymbol{x}, \boldsymbol{t})$ in the state space $\boldsymbol{R}^{\boldsymbol{n}}$ is given by [22]:

$$
s(x, t)=\left(\frac{d}{d t}+\lambda\right)^{n-1} \tilde{x}=0
$$

where $\lambda$ is the positive constant and calculate it is play important role to have the best performance. The main target in this methodology is kept the sliding surface slope $\boldsymbol{s}(\boldsymbol{x}, \boldsymbol{t})$ near to the zero. Therefore, one of the common strategies is to find input $\boldsymbol{U}$ outside of $\boldsymbol{s}(\boldsymbol{x}, \boldsymbol{t})[28]$.

$$
\frac{1}{2} \frac{d}{d t} s^{2}(x, t) \leq-\zeta|s(x, t)|
$$

where $\zeta$ is positive constant.

$$
\text { If } \mathbf{S}(\mathbf{0})>0 \rightarrow \frac{\mathrm{d}}{\mathrm{dt}} \mathbf{S}(\mathrm{t}) \leq-\zeta
$$

To eliminate the derivative term, it is used an integral term from $\mathrm{t}=0$ to $\mathrm{t}=\boldsymbol{t}_{\text {reach }}$

$$
\begin{aligned}
\int_{t=0}^{t=t_{\text {reach }}} \frac{d}{d t} S(t) & \leq-\int_{t=0}^{t=t_{\text {reach }}} \eta \\
& \rightarrow S\left(t_{\text {reach }}\right)-S(0) \\
& \leq-\zeta\left(t_{\text {reach }}-0\right)
\end{aligned}
$$

Where $t_{\text {reach }}$ is the time that trajectories reach to the sliding surface so, suppose $S\left(t_{\text {reach }}=0\right)$ defined as;

$$
0-S(0) \leq-\eta\left(t_{\text {reach }}\right) \rightarrow t_{\text {reach }} \leq \frac{S(0)}{\zeta}
$$

and

$$
\text { if } \begin{aligned}
S(0)<0 \rightarrow 0 & -S(0) \leq-\eta\left(t_{\text {reach }}\right) \\
& \rightarrow S(0) \leq-\zeta\left(t_{\text {reach }}\right) \\
& \rightarrow t_{\text {reach }} \leq \frac{|\boldsymbol{S}(\mathbf{0})|}{\eta}
\end{aligned}
$$

Equation (11) guarantees time to reach the sliding surface is smaller than $\frac{|\boldsymbol{S}(\boldsymbol{0})|}{\zeta}$ since the trajectories are outside of $S(t)$. 


$$
\text { if } S_{t_{\text {reach }}}=S(0) \rightarrow \operatorname{error}\left(x-x_{d}\right)=0
$$

suppose $\mathrm{S}$ is defined as

$$
\begin{aligned}
s(x, t)=\left(\frac{d}{d t}+\lambda\right) & \tilde{x} \\
& =\left(\dot{\mathbf{x}}-\dot{\mathbf{x}}_{\mathrm{d}}\right) \\
& +\lambda\left(\mathbf{x}-\mathbf{x}_{\mathrm{d}}\right)
\end{aligned}
$$

The derivation of $\mathrm{S}$, namely, $\dot{S}$ can be calculated as the following;

$$
\dot{S}=\left(\ddot{\mathbf{x}}-\ddot{\mathbf{x}}_{\mathbf{d}}\right)+\lambda\left(\dot{\mathbf{x}}-\dot{\mathbf{x}}_{\mathbf{d}}\right)
$$

A simple solution to get the sliding surface condition when the dynamic parameters have uncertainty is the switching control law [21-55]:

$$
U_{d i s}=\widehat{U}-K(\vec{x}, t) \cdot \operatorname{sgn}(s)
$$

where the switching function $\operatorname{sgn}(\mathbf{S})$ is defined as $[11,16]$

$$
\operatorname{sgn}(s)= \begin{cases}1 & s>0 \\ -1 & s<0 \\ 0 & s=0\end{cases}
$$

and the $\boldsymbol{K}(\overrightarrow{\boldsymbol{x}}, \boldsymbol{t})$ is the positive constant. Suppose by (7) the following equation can be written as,

$$
\begin{aligned}
\frac{1}{2} \frac{d}{d t} s^{2}(x, t)= & \dot{S} \cdot S \\
= & {[f-\hat{f}-K \operatorname{sgn}(s)] } \\
\cdot S & =(f-\hat{f}) \cdot S-K|S|
\end{aligned}
$$

and if the equation (11) instead of (10) the sliding surface can be calculated as

$$
\begin{aligned}
s(x, t)=\left(\frac{d}{d t}+\lambda\right)^{2} & \left(\int_{0}^{t} \tilde{x} d t\right) \\
& =\left(\dot{\mathbf{x}}-\dot{\mathbf{x}}_{\mathrm{d}}\right) \\
& +2 \lambda\left(\dot{\mathrm{x}}-\dot{\mathbf{x}}_{\mathrm{d}}\right) \\
& -\lambda^{2}\left(\mathrm{x}-\mathrm{x}_{\mathrm{d}}\right)
\end{aligned}
$$

in this method the approximation of $\boldsymbol{U}$ is computed as [26]

$$
\begin{aligned}
\widehat{U}=-\widehat{f}+\ddot{x}_{d}-2 & \lambda\left(\dot{\mathbf{x}}-\dot{\mathbf{x}}_{\mathbf{d}}\right) \\
& +\lambda^{2}\left(\mathbf{x}-\mathbf{x}_{\mathrm{d}}\right)
\end{aligned}
$$

\section{Methodol ogy}

Proposed methodology is focused on applied switching method in baseline methodology to increased stability of the main controller. Switching methodology is a nonlinear robust and stable method and linear baseline method is a nonlinear controller but it has a challenge in stability and robustness especially in presence of uncertainty and disturbance. Based on (13) to improve stability switching formulation is applied to baseline methodology;

$$
\begin{aligned}
\boldsymbol{\tau}=\boldsymbol{P F I} \times \operatorname{sgn} & \left(\ddot{\boldsymbol{q}}_{d}+\boldsymbol{K}_{v}\left(\ddot{\mathbf{x}}-\ddot{\mathbf{x}}_{\mathrm{d}}\right)\right. \\
& \left.+\lambda\left(\dot{\mathbf{x}}-\dot{\mathbf{x}}_{\mathbf{d}}\right)\right) \\
& +\boldsymbol{K}_{p}\left(\left(\dot{\mathbf{x}}-\dot{\mathbf{x}}_{\mathrm{d}}\right)\right. \\
& \left.\left.+\lambda\left(\mathbf{x}-\mathbf{x}_{\mathbf{d}}\right)\right)\right)
\end{aligned}
$$

To resolve uncertain problem this research is focused on to design SISO sliding mode switching baseline methodology. According to the linear system theory, convergence of the tracking error to zero is guaranteed [6]. Supervisory gains adjusted by partly sliding mode method. The result scheme is shown in Figure 2.

$$
\begin{gathered}
U_{d i s}=K(\vec{x}, t) \cdot \operatorname{sgn}(s) \\
S=\lambda e+\dot{e}
\end{gathered} \longrightarrow \text { To optimize the baseline Coefficient }
$$

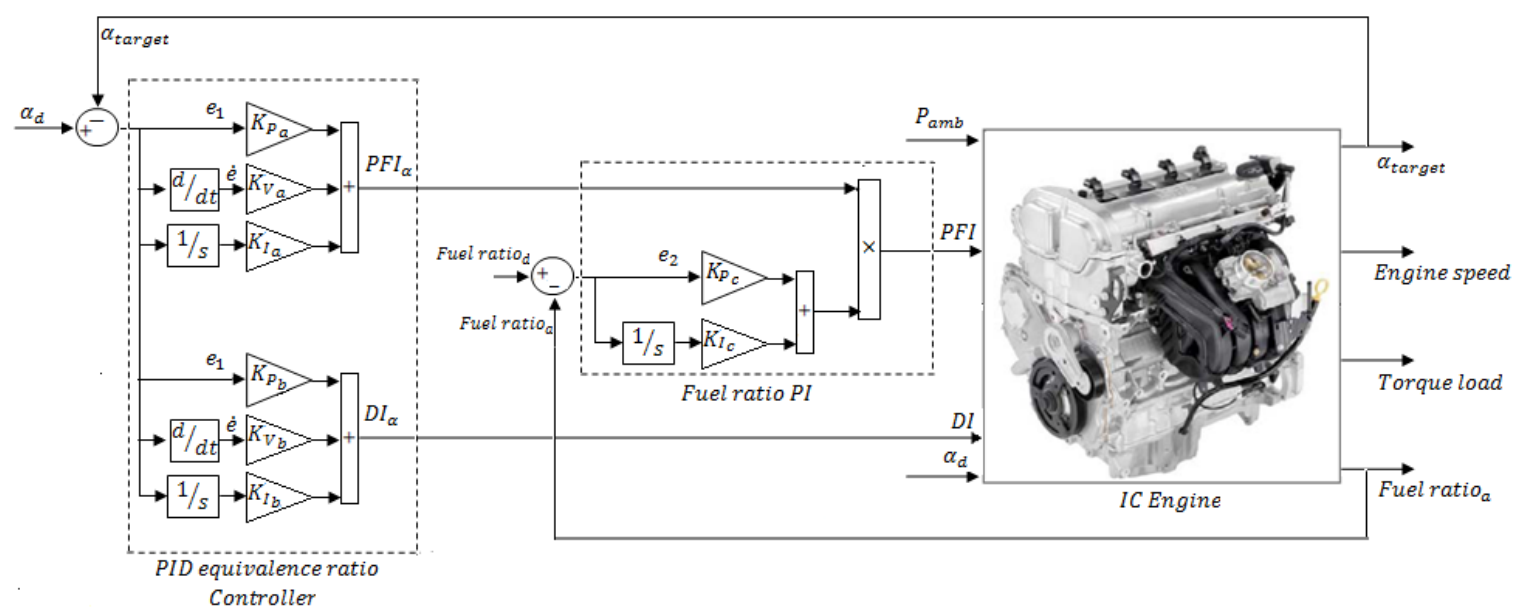

Fig. 2: Block diagram of a partly sliding mode optimizer baseline method: applied to IC engine 


\section{Results and Discussion}

This part is focused on compare between baseline method (BM) and baseline partly sliding mode fuel method (BPSFM). These two methods were tested by step fuel ratio and equivalence ratio. The simulation was implemented in MATLAB/SIMULINK environment.

Close loop response of fuel ratio without any disturbance: Figure 3 is shown the methodology of fuel ratio based on two methods: BPSFM and BM.
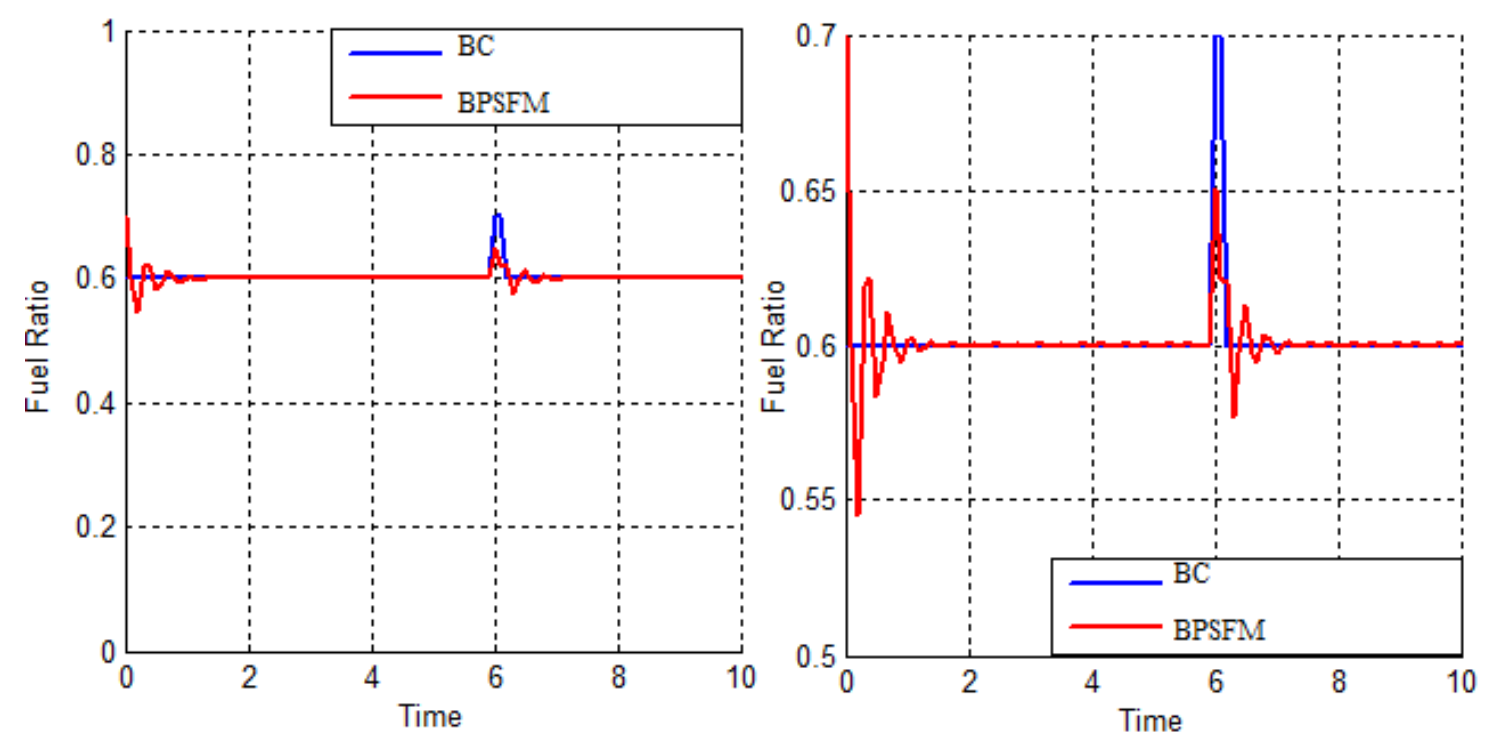

Fig. 3: BM vs. BPSFM without disturbance

Based on Figure 3; by comparing fuel ratio response without disturbance in BM and BPSFM, BPSFM's overshoot about $(\mathbf{0 . 0 \%})$ is lower than BC's (18\%).

Close loop response of fuel ratio in presence of torque load disturbance: Figure 4 shows the power disturbance elimination in BPSFM and BM with torque load disturbance for fuel ratio. The disturbance rejection is used to test the robustness comparisons of these two methodologies for fuel ratio. It found fairly fluctuations in $\mathrm{BM}$ responses.

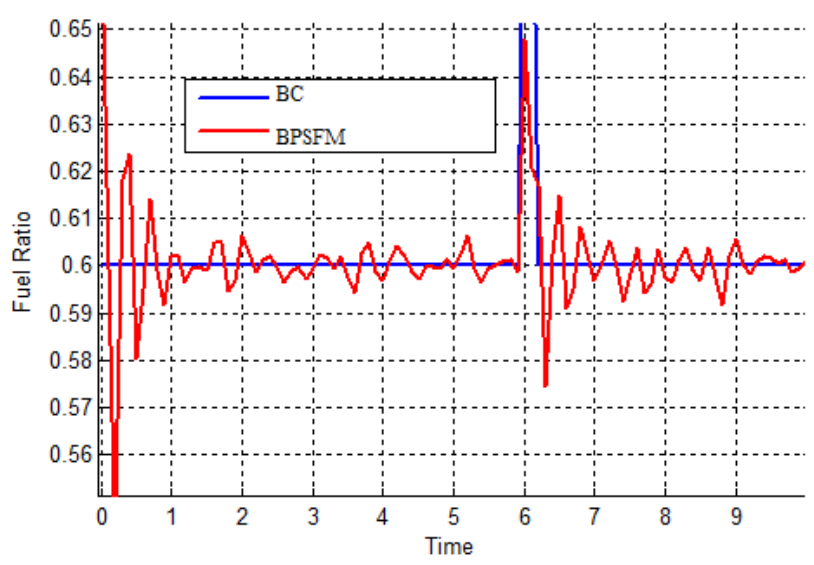

Fig. 4: BM vs. BPSFM with torque load disturbance

Based on Figure 4; by comparing fuel ratio response in presence of torque load disturbance in $\mathrm{BM}$ and BPSFM, BPSFM's overshoot about $(0 \%)$ is lower than
BM's (23\%). Based on Figure 4, BM has moderately oscillation in fuel ratio response with regard to torque load disturbance but BPSFM has stability in trajectory responses.

\section{Conclusion}

This paper reveals a new method for supervisory control of IC engine to reduce the fuel and fix the fuel ratio .This method is used to simultaneously control the mass flow rate of both port fuel injection (PFI) and direct injection (DI) systems to regulate the fuel ratio of PFI to DI to desired levels. The research results explain the supervisory performance of IC engine. In this context, this research proposes a new linear baseline methodologies for IC engine to reach the following target, improvement the fuel ratio performance by online tuning the baseline optimizer, development of system's supervisory method by new linear method, develop the business by design a small and cheaper controller model.

\section{Acknowledgments}

The authors would like to thank the anonymous reviewers for their careful reading of this paper and for their helpful comments. This work was supported by the SSP Research and Development Corporation Program of Iran under grant no. 2012-Persian Gulf-2B. 


\section{References}

[1] Heywood, J., “Internal Combustion Engine Fundamentals", McGraw-Hill, New York, 1988.

[2] J. G. Rivard, "Closed-loop Electronic Fuel Injection Control of the IC Engine," in Society of Automotive Engineers, 1973.

[3] J. F. Cassidy, et al, "On the Design of Electronic Automotive Engine Controls using linear Quadratic Control Theory," IEEE Trans on Control Systems, vol. AC-25, October 1980.

[4] W. E. Powers, "Applications of Optimal Control and Kalman Filtering to Automotive Systems," International Journal of Vehicle Design, vol. Applications of Control Theory in the Automotive Industry, 1983.

[5] N. F. Benninger, et al, "Requirements and Perfo mance of Engine Management Systems under Transient Conditions," in Society of Automotive Engineers, 1991.

[6] N. F. Benninger, et al, "Requirements and Perfo mance of Engine Management Systems under Transient Conditions," in Society of Automotive Engineers, 1991.

[7] C. H. Onder, et al, "Model-Based Multivariable Speed and Air-to-Fuel Ratio Control of an SI Engine," in Society of Automotive Engineers, 1993.

[8] S. B. Cho, et al, "An Observer-based Controller Design Method for Automotive Fuel-Injection Systems," in American Controls Conference, 1993, pp. 2567-2571.

[9] T. Kume, et al, "Combustion Technologies for Direct Injection SI Engine," in Society of Automotive Engineers, 1996.

[10] V. Utkin, "Variable structure systems with sliding modes," Automatic Control, IEEE Transactions on, No. 2, vol. 22, pp. 212-222, 2002.

[11] R. A. DeCarlo, S. H. Zak and G. P. Matthews, "Variable structure control of nonlinear multivariable systems: a tutorial," Proceedings of the IEEE, No. 3, vol. 76, pp. 212-232, 2002.

[12] K. D. Young, V. Utkin and U. Ozguner, "A control engineer's guide to sliding mode control," IEEE conference proceeding, 2002, pp. 1-14.

[13] O. Kaynak, "Guest editorial special section on computationally intelligent methodologies and sliding-mode control," IEEE Transactions on Industrial Electronics, No. 1, vol. 48, pp. 2-3, 2001.

[14] P. Kachroo and M. Tomizuka, "Chattering reduction and error convergence in the slidingmode control of a class of nonlinear systems," Automatic Control, IEEE Transactions on, No. 7, vol. 41, pp. 1063-1068, 2002.
[15] Farzin Piltan , M. A. Bairami, F. Aghayari, S. Allahdadi, "Design Adaptive Artificial Inverse Dynamic Controller: Design Sliding Mode Fuzzy Adaptive New Inverse Dynamic Fuzzy Controller," International Journal of Robotic and Automation, 3 (1): 13-26, 2012.

[16] J. Moura and N. Olgac, "A comparative study on simulations vs. experiments of SMCPE," IEEE conference proceeding, 2002, pp. 996-1000.

[17] Farzin Piltan , S. Allahdadi, M. A. Bairami, H. Nasiri, "Design Auto Adjust Sliding Surface Slope: Applied to Robot Manipulator," International Journal of Robotic and Automation, 3 (1): 27-44, 2012.

[18] Farzin Piltan , N. Sulaiman, Zahra Tajpaykar, Payman Ferdosali, Mehdi Rashidi, "Design Artificial Nonlinear Robust Controller Based on CTLC and FSMC with Tunable Gain," International Journal of Robotic and Automation, 2 (3): 205-220, 2011.

[19] Farzin Piltan, A. R. Salehi and Nasri B Sulaiman.," Design artificial robust control of second order system based on adaptive fuzzy gain scheduling," world applied science journal (WASJ), 13 (5): 1085-1092, 2011.

[20] Farzin Piltan, N. Sulaiman, Atefeh Gavahian, Samira Soltani, Samaneh Roosta, "Design Mathematical Tunable Gain PID-Like Sliding Mode Fuzzy Controller with Minimum Rule Base," International Journal of Robotic and Automation, 2 (3): 146-156, 2011.

[21] Farzin Piltan, A. Zare, Nasri B. Sulaiman, M. H. Marhaban and R. Ramli, , "A Model Free Robust Sliding Surface Slope Adjustment in Sliding Mode Control for Robot Manipulator," World Applied Science Journal, 12 (12): 2330-2336, 2011.

[22] Farzin Piltan, A. H. Aryanfar, Nasri B. Sulaiman, M. H. Marhaban and R. Ramli "Design Adaptive Fuzzy Robust Controllers for Robot Manipulator," World Applied Science Journal, 12 (12): $2317-$ 2329, 2011.

[23] Farzin Piltan, N. Sulaiman , Arash Zargari, Mohammad Keshavarz, Ali Badri , "Design PIDLike Fuzzy Controller With Minimum Rule Base and Mathematical Proposed On-line Tunable Gain: Applied to Robot Manipulator," International Journal of Artificial intelligence and expert system, 2 (4):184-195, 2011.

[24] Farzin Piltan, Nasri Sulaiman, M. H. Marhaban and R. Ramli, "Design On-Line Tunable Gain Artificial Nonlinear Controller," Journal of Advances In Computer Research, 2 (4): 75-83, 2011.

[25] Farzin Piltan, N. Sulaiman, Payman Ferdosali, Iraj Assadi Talooki, " Design Model Free Fuzzy 
Sliding Mode Control: Applied to Internal Combustion Engine," International Journal of Engineering, 5 (4):302-312, 2011.

[26] Farzin Piltan, N. Sulaiman, Samaneh Roosta, M.H. Marhaban, R. Ramli, “Design a New Sliding Mode Adaptive Hybrid Fuzzy Controller," Journal of Advanced Science \& Engineering Research , 1 (1): 115-123, 2011.

[27] Farzin Piltan, Atefe Gavahian, N. Sulaiman, M.H. Marhaban, R. Ramli, "Novel Sliding Mode Controller for robot manipulator using FPGA," Journal of Advanced Science \& Engineering Research, 1 (1): 1-22, 2011.

[28] Farzin Piltan, N. Sulaiman, A. Jalali \& F. Danesh Narouei, "Design of Model Free Adaptive Fuzzy Computed Torque Controller: Applied to Nonlinear Second Order System," International Journal of Robotics and Automation, 2 (4):232-244, 2011.

[29] Farzin Piltan, N. Sulaiman, Iraj Asadi Talooki, Payman Ferdosali, "Control of IC Engine: Design a Novel MIMO Fuzzy Backstepping Adaptive Based Fuzzy Estimator Variable Structure Control ," International Journal of Robotics and Automation, 2 (5):360-380, 2011.

[30] Farzin Piltan, N. Sulaiman, Payman Ferdosali, Mehdi Rashidi, Zahra Tajpeikar, "Adaptive MIMO Fuzzy Compensate Fuzzy Sliding Mode Algorith m: Applied to Second Order Nonlinear System," International Journal of Engineering, 5 (5): 380398, 2011.

[31] Farzin Piltan, N. Sulaiman, Hajar Nasiri, Sadeq Allahdadi, Mohammad A. Bairami, "Novel Robot Manipulator Adaptive Artificial Control: Design a Novel SISO Adaptive Fuzzy Sliding Algorithm Inverse Dynamic Like Method," International Journal of Engineering, 5 (5): 399-418, 2011.

[32] Farzin Piltan, N. Sulaiman, Sadeq Allahdadi, Mohammadali Dialame, Abbas Zare, "Position Control of Robot Manipulator: Design a Novel SISO Adaptive Sliding Mode Fuzzy PD Fuzzy Sliding Mode Control," International Journal of Artificial intelligence and Expert System, 2 (5):208-228, 2011

[33] Farzin Piltan, SH. Tayebi HAGHIGHI, N. Sulaiman, Iman Nazari, Sobhan Siamak, "Artificial Control of PUMA Robot Manipulator: A-Review of Fuzzy Inference Engine And Application to Classical Controller ," International Journal of Robotics and Automation, 2 (5):401-425, 2011.

[34] Farzin Piltan, N. Sulaiman, Abbas Zare, Sadeq Allahdadi, Mohammadali Dialame, "Design Adaptive Fuzzy Inference Sliding Mode Algorith m: Applied to Robot Arm," International Journal of Robotics and Automation , 2 (5): 283-297, 2011.
[35] Farzin Piltan, Amin Jalali, N. Sulaiman, Atefeh Gavahian, Sobhan Siamak, "Novel Artificial Control of Nonlinear Uncertain System: Design a Novel Modified PSO SISO Lyapunov Based Fuzzy Sliding Mode Algorithm ," International Journal of Robotics and Automation, 2 (5): 298$316,2011$.

[36] Farzin Piltan, N. Sulaiman, Amin Jalali, Koorosh Aslansefat, "Evolutionary Design of Mathematical tunable FPGA Based MIMO Fuzzy Estimator Sliding Mode Based Lyapunov Algorithm: Applied to Robot Manipulator," International Journal of Robotics and Automation, 2 (5):317-343, 2011.

[37] Farzin Piltan, N. Sulaiman, Samaneh Roosta, Atefeh Gavahian, Samira Soltani, "Evolutionary Design of Backstepping Artificial Sliding Mode Based Position Algorithm: Applied to Robot Manipulator," International Journal of Engineering, 5 (5):419-434, 2011.

[38] Farzin Piltan, N. Sulaiman, S.Soltani, M. H. Marhaban \& R. Ramli, "An Adaptive sliding surface slope adjustment in PD Sliding Mode Fuzzy Control for Robot Manipulator," International Journal of Control and Automation , 4 (3): 65-76, 2011.

[39] Farzin Piltan, N. Sulaiman, Mehdi Rashidi, Zahra Tajpaikar, Payman Ferdosali, "Design and Implementation of Sliding Mode Algorithm: Applied to Robot Manipulator-A Review ," International Journal of Robotics and Automation, 2 (5):265-282, 2011.

[40] Farzin Piltan, N. Sulaiman, Amin Jalali, Sobhan Siamak, and Iman Nazari, "Control of Robot Manipulator: Design a Novel Tuning MIMO Fuzzy Backstepping Adaptive Based Fuzzy Estimator Variable Structure Control ," International Journal of Control and Automation, 4 (4):91-110, 2011.

[41] Farzin Piltan, N. Sulaiman, Atefeh Gavahian, Samaneh Roosta, Samira Soltani, "On line Tuning Premise and Consequence FIS: Design Fuzzy Adaptive Fuzzy Sliding Mode Controller Based on Lyaponuv Theory," International Journal of Robotics and Automation, 2 (5):381-400, 2011.

[42] Farzin Piltan, N. Sulaiman, Samaneh Roosta, Atefeh Gavahian, Samira Soltani, "Artificial Chattering Free on-line Fuzzy Sliding Mode Algorith m for Uncertain System: Applied in Robot Manipulator," International Journal of Engineering, 5 (5):360-379, 2011.

[43] Farzin Piltan, N. Sulaiman and I.AsadiTalooki, "Evolutionary Design on-line Sliding Fuzzy Gain Scheduling Sliding Mode Algorithm: Applied to Internal Combustion Engine," International Journal 
of Engineering Science and Technology, 3 (10):7301-7308, 2011.

[44] Farzin Piltan, Nasri B Su laiman, Iraj Asadi Talooki and Payman Ferdosali.," Designing On-Line Tunable Gain Fuzzy Sliding Mode Controller Using Sliding Mode Fuzzy Algorithm: Applied to Internal Combustion Engine," world applied science journal (WASJ), 15 (3): 422-428, 2011.

[45] Farzin Piltan, N. Sulaiman, M. H. Marhaban, Adel Nowzary, Mostafa Tohidian," "Design of FPGA based sliding mode controller for robot manipulator," International Journal of Robotic and Automation, 2 (3): 183-204, 2011.

[46] Farzin Piltan, S. Siamak, M. A Bairami, I. Nazari,” Gradient Descent Optimal Chattering Free Sliding Mode Fuzzy Control Design: Lyapunov Approach," International Journal of Advance Science and Technology, 45: 73-90, 2012.

[47] Farzin Piltan, H. Rezaie, B. Boroomand, Arman Jahed," Design robust back stepping online tuning feedback linearization control applied to IC engine," International Journal of Advance Science and Technology, 42: 183-204, 2012.

[48] Farzin Piltan, I. Nazari, S. Siamak, P. Ferdosali ,"Methodology of FPGA-based mathematical error-based tuning sliding mode controller" International Journal of Control and Automation, 5(1): 89-110, 2012.

[49] Farzin Piltan, M. A. Dialame, A. Zare, A. Badri ,"Design Novel Lookup table changed Auto Tuning FSMC: Applied to Robot Manipulator" International Journal of Engineering, 6(1): 25-40, 2012.

[50] Farzin Piltan, B. Boroomand, A. Jahed, H. Rezaie ,'Methodology of Mathematical ErrorBased Tuning Sliding Mode Controller" International Journal of Engineering, 6(2): 96-112, 2012.

[51] Farzin Piltan, F. Aghayari, M. R. Rashidian, M. Shamsodini, "A New Estimate Sliding Mode Fuzzy Controller for Robotic Manipulator" International Journal of Robotics and Automation, 3(1): 45-58, 2012.

[52] Piltan, F., et al. "Design sliding mode controller for robot manipulator with artificial tunable gain". Canaidian Journal of pure and applied science, 5 (2), 1573-1579, 2011.

[53] Farzin Piltan, A. Hosainpour, E. Mazlomian, M.Shamsodini, M.H Yarmahmoudi. "Online Tuning Chattering Free Sliding Mode Fuzzy Control Design: Lyapunov Approach" International Journal of Robotics and Automation, 3(3): 2012.

[54] Farzin Piltan, S. Emamzadeh, Z. Hivand, F. Shahriyari \& Mina Mirazaei ." PUMA-560 Robot
Manipulator Position Sliding Mode Control Methods Using MATLAB/SIMULINK and Their Integration into Graduate/Undergraduate Nonlinear Control, Robotics and MATLAB Courses" International Journal of Robotics and Automation, 3(3): 2012.

[55] Farzin Piltan, J. Meigolinedjad, S. Mehrara, S. Rahmdel. "Evaluation Performance of $2^{\text {nd }}$ Order Nonlinear System: Baseline Control Tunable Gain Sliding Mode Methodology" International Journal of Robotics and Automation, 3(3): 2012.

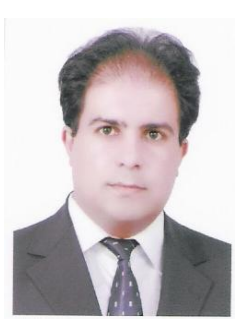

Farzin Piltan was born on 1975, Shiraz, Iran. In 2004 he is jointed the research and development company, SSP Co, Shiraz, Iran. In addition to 7 textbooks, Farzin Piltan is the main author of more than 50 scientific papers in refereed journals. He is editorial board of international journal of control and automation (IJCA), editorial board of International Journal of Intelligent System and Applications (IJISA), editorial board of IAES international journal of robotics and automation, editorial board of International Journal of Reconfigurable and Embedded Systems and reviewer of (CSC) international journal of robotics and automation. His main areas of research interests are nonlinear control, artificial control system and applied to FPGA, robotics and artificial nonlinear control and IC engine modelling and control.

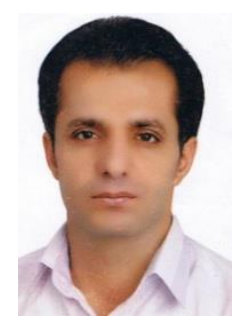

Mehdi Akbari is an industrial management researcher of research and development company SSP. Co. $\mathrm{He}$ is now pursuing his Master in industrial management. $\mathrm{He}$ is an expert Industrial and Quality Management in this company. His research activities deal with the IC engine control, artificial intelligence and supply chain management.

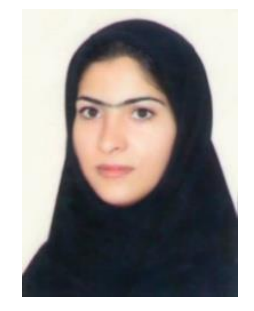

Mojdeh Piran is an industrial management researcher of research and development company SSP. Co. She is now pursuing her Master in industrial management. She is an expert Industrial and Quality Management in this company. Her research activities deal with the IC engine control, artificial intelligence and expert system. 


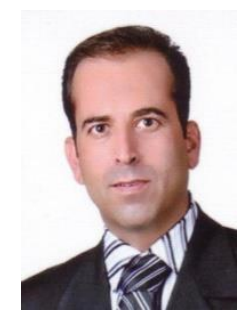

Mansour Bazregar is an industrial management researcher of research and development company SSP. Co. $\mathrm{He}$ is now pursuing his Master in industrial management. $\mathrm{He}$ is an expert Industrial and Quality Management in this company. His research activities deal with the IC engine control and supply chain management.

How to cite this paper: Farzin Piltan, Mehdi Akbari, Mojdeh Piran, Mansour Bazregar,"Design Model Free Switching Gain Scheduling Baseline Controller with Application to Automotive Engine", International Journal of Information Technology and Computer Science(IJITCS), vol.5, no.1, pp.65-73, 2013.DOI: $10.5815 /$ ijitcs.2013.01.07 